\title{
A methodological examination of multidisciplinary research of mak yong theatre: text, heritage, and performance Pemeriksaan metodologis atas pendekatan multidisipliner dalam kajian tentang teater mak yong: teks, warisan budaya, dan pertunjukan
}

\author{
Alan Darmawan \\ Department of Languages and Cultures of Southeast \\ Asia, Universität Hamburg, Germany \\ darmawn29@gmail.com
}

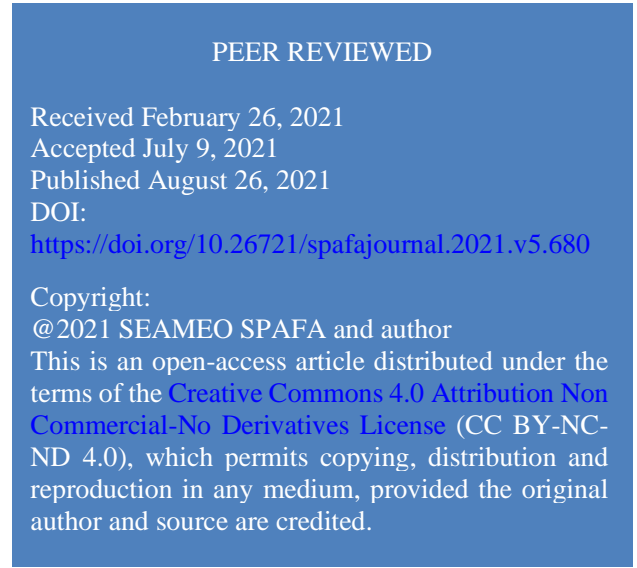

\begin{abstract}
Previous studies of mak yong theatre in Indonesia looked at the art form as a given tradition, and described its elements and performance structure. Such an approach is inadequate to investigate mak yong in the current social and cultural context. State institutions, the local government, communities, performers, and other agents have revived and constantly (re)shaped mak yong theatre and its presentation as a commodified Malay identity marker. Heritage formation, local identity politics, and tourist festivals promoted mak yong as a revived traditional form of theatre practice, an intangible heritage, and a stage performance. So how should the above aspects be approached and the social processes that shape them disentangled? This article examines the relevance of multidisciplinary approaches and demonstrates how the perspectives of anthropology, heritage studies, and philology work in studying mak yong and its current production in the Riau Islands.

Kajian terdahulu tentang teater mak yong di Indonesia umumnya melihat kesenian ini sebagai tradisi yang “demikian adanya”, dan mendeskripsikan elemen dan struktur pertunjukannya. Pendekatan semacam ini tidak lagi memadai untuk menelaah mak yong dalam konteks sosial dan budaya saat ini. Mak yong disajikan sebagai tradisi yang dibangkitkan kembali dan senantiasa dibentuk ulang oleh lembaga negara, pemerintah lokal, komunitas, aktor, dan pelaku-pelaku lainnya, sebagai satu di antara penanda identitas Melayu yang dikomodifikasi. Pelembagaan warisan budaya, politik identitas lokal, dan pariwisata budaya memajukan mak yong sebagai tradisi yang dihidupkan kembali, warisan budaya takbenda, dan pertunjukan panggung. Lantas, bagaimana menelaah aspek-aspek di atas dan mengurai proses sosial yang membentuknya? Artikel ini menguji relevansi pendekatan antropologi, heritage studies, dan filologi, dan menunjukkan cara bekerjanya dalam mengkaji mak yong dan produksinya saat ini di Kepulauan Riau.
\end{abstract}

Keywords: mak yong, revival, multidisciplinary approaches, text, heritage, performance | mak yong, kebangkitan, pendekatan multidisiplin, teks, warisan budaya, pertunjukan 


\section{Introduction}

This article examines the relevance of multidisciplinary approaches to study mak yong theatre. It aims to demonstrate how I employ them to analyze the theatre form. Mak yong is a form of theatrical performance that combines rituals, stories, music, dance, slapstick comedy, and dialogue. The geographic origin of mak yong, whether from Patani or Kelantan, remains debatable (cf. Sheppard 1972: 58; Yousof 2018: 21-22). We have very little evidence about its emergence. Some Malay writings, colonial reports, and photographs reveal only its presence as far back as the nineteenth century. However, we can be sure about the spread of mak yong theatre traditions, as some of them still remain to this day in the southern provinces of Thailand (Tan and Shafii 2021), the northern states of the Malay Peninsula (Hardwick 2020), and Indonesia's North Sumatra and Riau Islands.

The earliest record of mak yong in the Riau Islands dates back to the mid-nineteenth century. Written in 1861, a Malay poem titled Syair Perkawinan Kapitan Tik Sing reports about mak yong performances at the wedding party of the son of Chinese Captain Oei Tik Sing in Tanjungpinang and at the royal court of Riau-Lingga Sultanate on Penyengat Island (Menick 1988). Other poems written in the mid-nineteenth century in the Riau Islands entitled Syair Awai and Syair Raja Nur Peri containing fictional stories may indicate the readers' and authors' knowledge about mak yong. ${ }^{1}$ A photograph printed in the late 1890s shows a group of mak yong performers in front of the royal house of Riau-Lingga (Haks 2005, Photo No. 31). Only since the early 1960s did mak yong wane due to economic decline in the border area of Indonesia and Malaysia (where the Riau Islands are situated) as a result of the political turbulence between the two countries. Mak yong turned into a dormant tradition in the context of modernization of the new nation of Indonesia in the 1970s.

Previous studies on mak yong in Indonesia were carried out during this state of dormancy. These studies attempt to document mak yong, define its form and elements, and describe its performance structure (Syamsuddin 1982; Sastrosuwondho 1985; Lumowah 1996; Pudentia MPSS 2000), as well as its plays in the narrative form (Al Azhar 1989). They are mostly related to the documentation project of "traditional arts" in Indonesia. This project aimed to record cultural forms and practices as part of the efforts of constructing regional and national cultures and identities in the period between the 1970s and 1990s. The Indonesian state made an inventory of traditional cultures that represented the regional cultures. In a hierarchical construction, the state defines that the "peaks" of regional cultures constitute the national culture. ${ }^{2}$ The documentation project took place in this search for a basis of the national culture and identity.

In the case of mak yong, there were attempts to commission performances and to record and study it. Pudentia MPSS, who documented the training and rehearsal of a mak yong troupe in the Riau Islands as preparations for the stage performances in the early 1990s, called these efforts "revitalization" (2010). However, attention to local cultures in the context of Indonesian politics of culture at that time was devoted to the making of the inventory of regional cultures. In Riau Province (then, including the Riau Islands), the Indonesian state established a centre for the study

\footnotetext{
${ }^{1}$ See Van der Putten (1997: 120). For the Syair Raja Nur Peri, see Klinkert 140.

${ }^{2}$ For more discussion about cultural policy, national culture, and regional identity construction in the "New Order" Indonesia, see Jones (2013).
} 
and documentation of Malay culture in Tanjungpinang in 1985, which served as the agent of the inventorying project. ${ }^{3}$ This project served the national interests of defining "traditional arts" rather than revitalizing their roles in society.

In this article, I argue that the approach used in previous studies is inadequate to understand mak yong in the current context in the Riau Islands. Politics of heritage, regional identity formation and tourist promotion contribute to reconfigure local culture, reinvent heritage, and reinstate traditional practices. Mak yong has been revived and reshaped for current art production, consumption, and other purposes of identity politics. How should we approach such a revived tradition in this complex situation? I will demonstrate multidisplinary approaches to study mak yong, which look at the art form as text, heritage, and performance. But first, we will look at mak yong, its form, and groups of performers that are now active in theatre production in social, cultural, and political context in the Riau Islands.

\section{Mak yong in Riau Islands}

Mak yong theatre focuses on the lives of nobles with their clown-servants. It manifests through stage performance a cosmological concept of the heavenly kingdom and its pantheon, which are based in the life setting of an earthly kingdom. The stories play through stereotypical characters, such as king and prince (Pak Yong); queen and princess (Mak Yong); and royal attendants (Awang Pengasuh and Inang Pengasuh). The play presents several settings—a royal palace, village, jungle, and the sea-with typical Malay names. The orchestra consists of musical instruments from the Malay music tradition, as well as songs and dialogues in the Malay language- using the Johor-Riau dialect. The traditional pattern of movements forms mak yong dances. Complimentary to this, two ritual practices open and close mak yong performances.

A mak yong performance starts with a prelude, a ritual-like dance and song before the three-string fiddle, called mengadap rebab. Mak yong's play departs from this sequence that structures the main part of the performance. It has a repertoire of magical adventure stories. Scholars who have grounded their research on Kelantanese mak yong structure twelve stories in a "tree" model derived from Dewa Muda as the base story (cerita pangkal) (Hardwick 2013: 90; Yousof 1982: 111-12). Such a stemma does not occur as an aspect of the mak yong tradition in the Riau Islands; instead, it is a collection of stories that forms a repertoire of the art form. Several of the most frequently performed plays at festivals include Raja Bungsu Sakti, Putri Timun Muda, Raja Lak Kenarong, Wak Perambun, and Putri Siput Gondang. ${ }^{4}$ Another element that distinguishes mak yong tradition in the Riau Islands from that of Kelantan is the masks, which male actors wear in performances.

\footnotetext{
${ }^{3}$ The centre is now known as Balai Pelestarian Nilai Budaya/BPNB (Institute for the Preservation of Cultural Values).

${ }^{4}$ Raja Bungsu Sakti recounts a story about Prince of Negeri Lenggang Cahaya who wanders to Negeri Gunung Berintan and gets married to the princess of the kingdom. Putri Timun Muda recounts a story about a princess whose husband is instructed by the king to hunt a deer for him. The princess accompanies her husband in the jungle. There her husband is killed by the antagonistic people of the forest but is then saved by the god Betala Guru. Raja Lak Kenarong features a story about a prince (and his mother) who is driven out from the palace by the king at the behest of his new wife (who is an incarnation of a genie). The prince wanders and finds a village in which he gets trained in martial arts by a guru and finally accomplishes his mission to take back the throne. Wak Perambun is a story about an old warrior appointed by the king to look for deer in the jungle. Although he did not find one, he brings home one of the princesses who flew down to take a bath in a pond in the jungle. Putri Siput Gondang is the story about a queen driven out from the palace due to giving birth to a big conch. In their exile, a little girl comes out from the snail. At the end of the story, they return to the palace and have their positions restored.
} 
The presence of mak yong currently in the Riau Islands is from a revived tradition since the early 2000s. It has been reconstructed and presented through different media. There are four groups that are now active in theatre production and regenerating mak yong performers. They are based in Mantang Island (Sanggar Bungsu Sakti/SBS), in Kijang town (Sanggar Mak Yong Warisan/SMW), in Tanjungpinang (Yayasan Konservatori Seni/YKS), and in Setokok, Batam (Sanggar Pantai Basri/SPB). Currently, mak yong presentations vary, namely through museum displays, short clips in television programmes, and stage performances at cultural festivals-with different types of stages and durations. In addition to this, discourse in print and electronic media is also part of the efforts of representing mak yong to the public. These presentations and representations of mak yong indicate attention to the art form currently, which is interconnected with the current social, economic, and political interests.

Political decentralization in Indonesia gives autonomy to the regional government to pursue local interests and (re)construct regional identities. Established in 2004, the Riau Islands Province reinvented local Malay heritage and reconstructed Malayness as a regional identity. The local governments promoted mak yong as one of the iconic cultural representations and commodified it as one of the trourist attractions performed at government-spronsored cultural festivals. Mak yong's stage properties (costumes, jewelry, and musical instruments) are displayed in local museums to construct the narrative connecting the present-day Riau Islands to the past (Figures 1 and 2). Tanjungpinang's Museum Sultan Sulaiman Badrul Alamsyah is one of the local museums that exhibits mak yong as one of the selected traditions representing the Malay cultural achievement in the nineteenth century, which draws a link that connects the city with the Riau-Johor Sultanate.
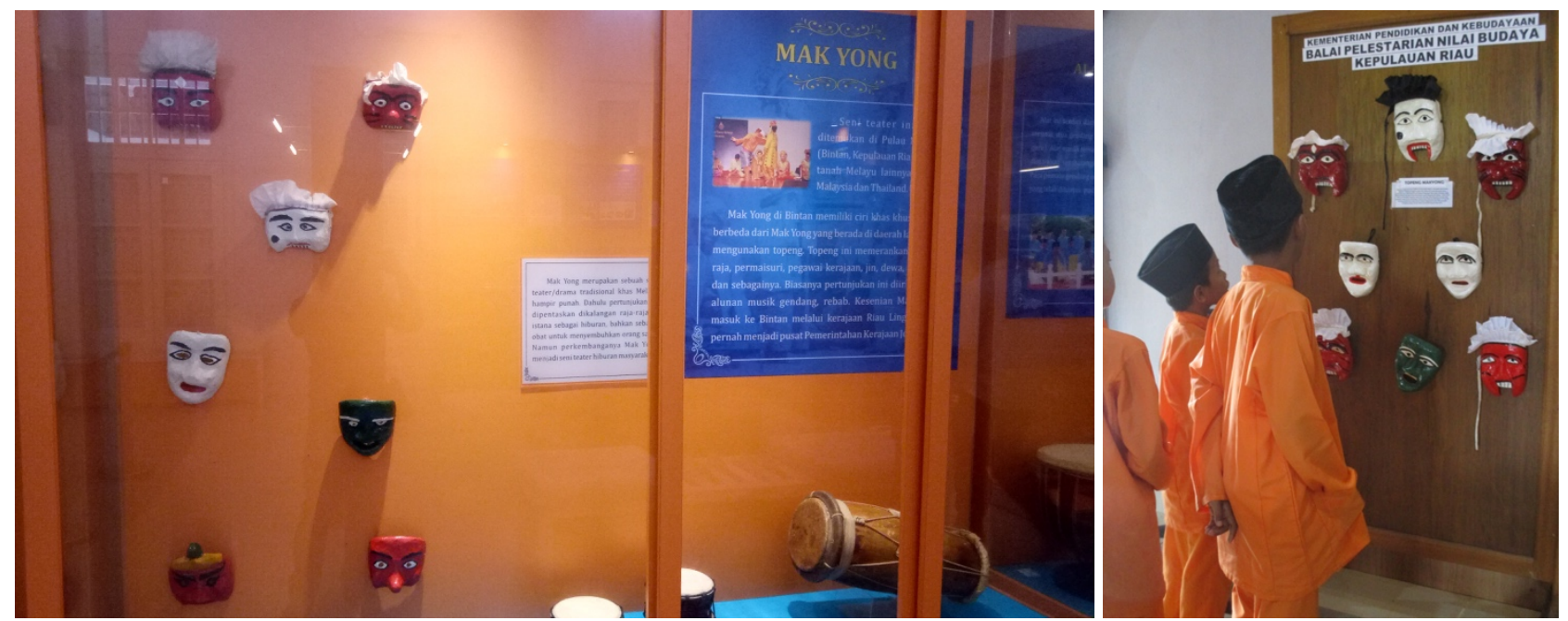

Figs. 1 and 2

Left: The exhibition of mak yong stage property in Museum Sultan Sulaiman Badrul Alamsyah, Tanjungpinang, September 2018. Right: Mak yong exhibition in Museum Linggam Cahaya, Lingga, during the Festival Tamadun Melayu, November 2017. Source: Photos by Alan Darmawan.

On a different scale of cultural configuration, the Indonesian state encourages the making of official heritage. The Intangible Heritage Committee of Indonesia proclaimed mak yong as national heritage in 2013. A multi-stage heritage formation-from the district, provincial, and up to the national level to step further for international recognition from UNESCO-has involved the local community in the formative process of official heritage. This has stimulated the community's awareness of owning heritage. For example, in Bintan District, the village administration and 
people in Mantang Lama organized a mak yong festival (Festival Mak Yong Mantang) in 2018 and 2019. The festival staged mak yong as performed by groups of school children. This aimed to show the new generation of performers-implying the preservation and the transmission of the tradition from one to the next generation-and pursue the recognition of being the foremost place of the development of mak yong in the region. Mak yong has been revived in this situation for making the national heritage, organizing tourist festivals, shaping regional identity, and evoking the community's sense of heritage ownership.

In this context, I found that mak yong is constantly (re)shaped, (re)invented, and reinterpreted to be adjusted to the interests of local identity politics, heritage formation, and the tourist industry. These interests have shaped and accentuated three aspects of mak yong in the current production and consumption, namely as a form of traditional practices or texts, an intangible heritage, and a stage performance. To approach these aspects, I look at mak yong from the perspectives of anthropology, heritage studies, and philology to understand the social processes that constitute the oral text, the heritage, and the meaning-making in the performance process.

\section{Mak yong as text}

Texts are made of words or tissues of words, and they are forms of action that are used to do things (Barber 2007:1, 3). Texts do not exclusively address what is written, but also the things that are connected to a form that is composed of words. The central notion of text is weaving or fabricating words, many of which are detachable from the flow of conversation and could be recontextualized in different contexts (Barber 2007: 21). Textuality refers to compositionality. I apply this to mak yong. As a text, mak yong is a form of practices, a theatre form, which is constituted by the elements composed of words: stories, songs, dialogues, and the myth of origin that underlies the belief about its existence. A set of rules preserves the structure of mak yong theatre, to which performers refer to instantiate it in actual performance. However, a certain event gives the opportunities to the performers to improvise particular chunks or parts, such as songs, quatrains, dialogues, and acting, which subsequently may contribute to altering the tradition. I look at such processes from a framework that views the constitution of oral text as a combination of freezing and creative improvisation processes (Barber 2007: 68).

According to the above framework, mak yong is not a final form. It is constantly (re)shaped. In the case of mak yong's revival, the performers and the state agencies attempted to reconstitute the art form and adjust it to the current context of identity construction, heritage formation, and tourist promotion. They brought the "text" into live performances, which have subsequently created a reformed version of mak yong. For example, mak yong has been reconstituted and adjusted to the current taste and interests of the organizers of cultural festivals - with a shortened duration, refined costumes, changes in the opening and closing rituals, and a flexiblity in the styles of stage. The SBS group in Mantang performs mak yong in a square, wooden shed (Figure 3). However, this troupe happened to perform on the proscenium stage at Festival Teater Bintan in 2017 in Kijang town as the organizers of the festival provided that kind of stage. At the same festival, the SMW troupe also performed on the proscenium stage (Figure 4). Another event such as Festival Tamadun Melayu in Lingga in 2017 gave the opportunity to the YKS to perform on the arena stage at ground level (Figure 5). Moreover, the SBS troupe had no rebab player, and hence, never performed rebab in the prelude sequence. As a result, the SBS performers prefered to call it betabek rather than mengadap rebab. The YKS troupe consistently performed this sequence with a rebab player accompanying the betabek song (Figure 5). With regard to the duration of the performance at cultural festivals (usually 30 minutes as allotted by the organizers), the SBS and SMW cut their peformances at a certain 
transition point. However, the leader of YKS, who held a high-ranking position with the local bureaucracy, was able to convince the organizers for a longer duration and condensed the stories to become a 60 -minute and a 120 -minute performances.

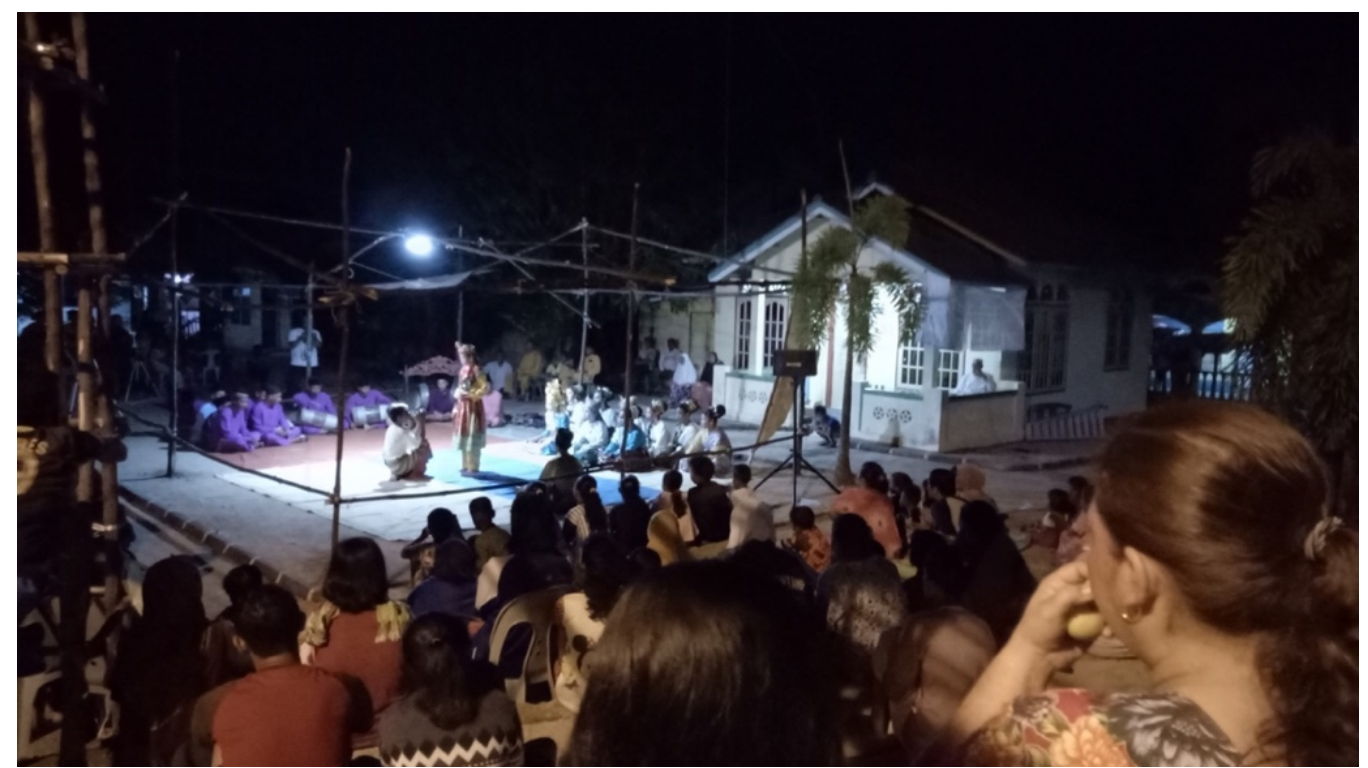

Fig. 3 Mak yong performance of Raja Bungsu Sakti by the Sanggar Bungsu Sakti troupe in the arena stage made of wood in Mantang Lama, Mantang Island, the Riau Islands, September 2018. Source: Photo by Alan Darmawan.

The above efforts are simultaneous processes in (re)forming mak yong with an adjustment to the current need and instantiate it in the stage performance, which subsequently alters the traditional practices. In this light, the revival of mak yong does not appear as an attempt to reinstate an authoritative text, but rather as an effort of reconstructing a form of practices with selections of certain parts and negotiations with current interests. An example of this is different attitudes of the groups of performers in dealing with the opening and closing rituals (buka tanah and tutup tanah) in the context of the dissemination of a more conservative form of Islam. The SBS retained but simplified the rituals. Opposite to this, the SMW omitted the rituals unless they were specifically requested to perform them. Meanwhile, the YKS changed these shamanistic rituals into Islamic rituals with prayers taken from the Quran's Surah Yasin. This approach suggests that we should look at mak yong not as a given tradition but as the reconstitution of a form of practices, which is meaningful only if we look at it as part of the undertakings of recontextualization and reinterpretation of the tradition. In this sense, mak yong theatre tradition has been recreated as one aspect of Malay heritage in the present. 


\section{Mak yong as heritage}

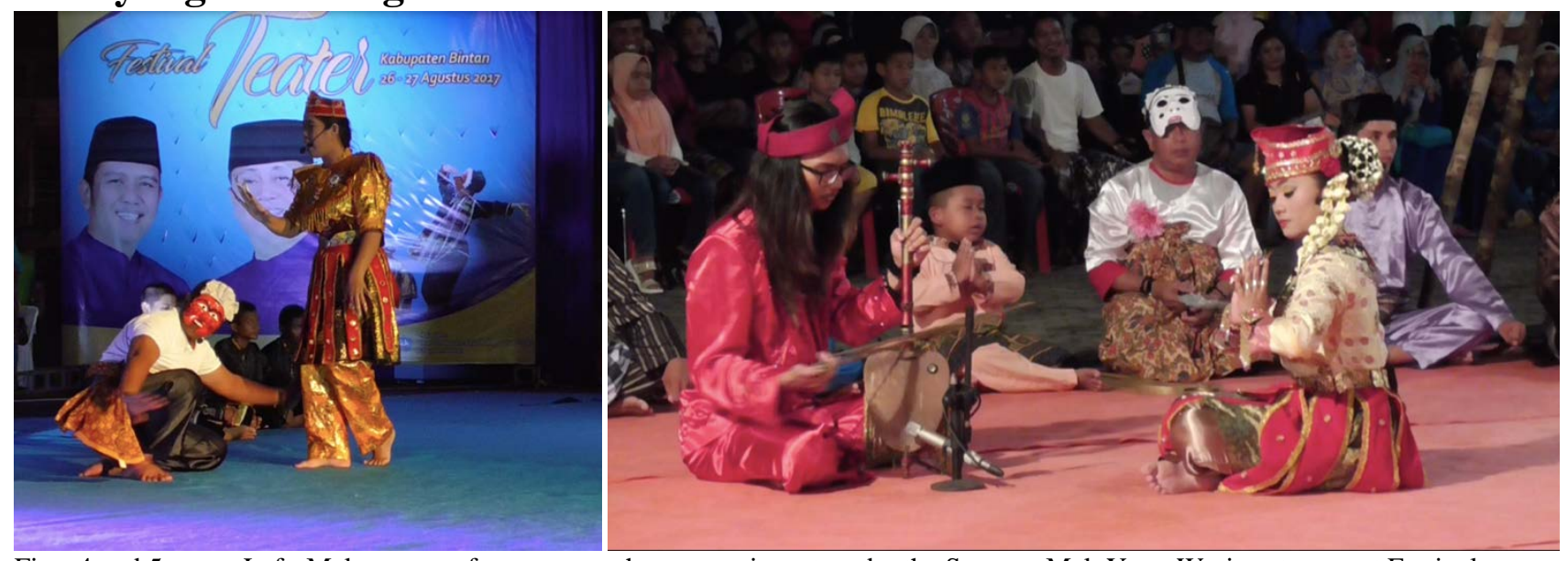

Figs. 4 and $5 \quad$ Left: Mak yong performance on the proscenium stage by the Sanggar Mak Yong Warisan troupe at Festival Teater Bintan in Kijang town in August 2017. Right: Mak yong performance of Raja Bungsu Sakti on the earthen stage by the Yayasan Konservatori Seni Tanjungpinang troupe at Festival Tamadun Melayu in Daik, Lingga, in November 2017. Source: Photos by Alan Darmawan.

Heritage is a version of the past obtained through objects and display, representation and engagement, sites and events, memories, and commemorations (Waterton and Watson 2015: 1). The centre of attention of heritage studies is "objects" (material and immaterial entities) and practices around them (discursive and/or performative). From this point of view, I approach mak yong as heritage to look at the social processes that make the art form heritage. In this heritage formation, certain agents or institutions selected mak yong as an official heritage of Indonesia through discourses, exhibitions, and stage performances. The state and local authorities control heritage discourse and regulate the procedures to constitute official heritage, and objectify and authenticate it through documentation, registration, and listing. An example of this is in the efforts of the government of Bintan District in making a heritage list of Bintan and especially in mak yong. Hence, mak yong was made into an artistic representation of Bintan. In Tanjungpinang and Lingga, mak yong masks and musical instruments were exhibited in local museums, namely Museum Sultan Sulaiman Badrul Alamsyah and Museum Linggam Cahaya (Figures 1 and 2). Through the museum exhibitions, the local governments created an official discourse about mak yong, which have been made as part of the whole constructed narrative of Malay heritage connecting the Riau Islands with the former Malay kingdoms of Riau-Johor (1722-1787) and Riau-Lingga (1787-1911). Moreover, mak yong was made into an iconic heritage performing arts of the Riau Islands and also declared as national heritage of Indonesia in 2013.

The above attempts show the making of mak yong into an official heritage, something that is formally registered, listed, documented, and officially recognized by the state. However, this is not a final effort of heritage formation, but rather, it stimulates other undertakings to remake and reaffirm the ownership of mak yong as an inheritance (warisan). In this light, recognition from the state and the local government has evoked a pride and a sense of belonging of heritage within the local community. The people of Mantang claim to be the owners of mak yong tradition. The performers of SBS regard their practices as original and have accused other performers from SMW and YKS of practicing "false" traditions. Likewise, the SMW and YKS troupes have defended their positions by drawing a link to the previous generations of performers in Mantang. Hence, these tensions at the local level have stimulated awareness of the current generation of practitioners about their inheritance. 
For the troupes like SBS, SMW, and YKS, awareness of owning heritage practices of mak yong are at the core of the efforts of regeneration of performers. It is the fear of loss of the senior performers and the pride of the younger generations of practicing mak yong that underlie the inheritance and the regeneration. The younger performers inherit mak yong from senior performers and conceive it as their own, make it their daily practices, and perform it on stage on certain occasions, such as cultural festivals. In addition to this is the appropriation of mak yong elements, such as dance and music by groups of local artists in their music and dance productions. An example is the adaptation of mak yong songs into a popular song titled "Progressive Makyong” by Samudra Ensemble, a music group in Tanjungpinang. This song gained popularity among younger generations in the Riau Islands as it was uploaded on YouTube and launched as part of the Samudra Ensemble's first music album, Sedayoung Kepri, in December 2017. With these attempts of (re)shaping and appropriating heritage on a local scale, part of the local communities and groups of mak yong performers reaffirm their heritage ownership.

It is the above-mentioned efforts that constitute mak yong as heritage. Heritage formation of mak yong should be looked at as the entirety of attempts of making an official heritage, as well as discourse and art production that reaffirm the heritage ownership. Discursive, creative, and performative efforts are included in this heritage formation. The discourses are in local media, museums, or in the narratives supporting the claim of the groups of performers. Also, the creative process of apropriating mak yong dance and music contribute to such a formation. The performative action of showing the younger performers and performing mak yong on stage as a Malay heritage are also part of the whole performative practices. In this sense, I consider another important aspect of mak yong, which is the stage performance.

\section{Mak yong as performance}

Mak yong's stage performance is another dimension of the theatre form that I examine. In this regard, I take into consideration the performance context of cultural festivals and the social context of the Riau Islands, which gives significance to the theatre form and shape meanings. The stage performance is shaped by performers and audiences. It takes place in the particular context of tourist promotion and regional identity formation. The expectation of the public in watching a performance of heritage is also considered. In this context, both the performers and the audience construct the stage performance through their interactions during the staging event. Hence every gesture, word, joke, and other symbols function to communicate messages and enliven the performance. Nevertheless, the previous studies overlooked the roles of symbols in the performance process (cf. Al Azhar 1989, Pudentia MPSS 2000). They mostly analyzed the narrative aspects of mak yong plays, motives in the stories, patterns, and formulas, which neglected the performance aspect. In my view, the actual performance is important because it is the instantiation of the revived tradition and the projection of the local politics of arts and culture. A stage performance is an event where communities see the image of a collective identity and attach feelings to it through their engagement by making use and making sense of symbols in the performance process. Moreover, the stage performance should be located in a societal context to understand what particular symbols may imply in a certain social context. Accordingly, I employ certain techniques with philological principles to analyse the transcription of mak yong performance to show how the symbols work in stage performances. This philological approach is called "performance philology" (Arps 2016). 
Referring to Bernard Arps (2016), I apply the philological methods that serve as analytical tools to deal with every unit of symbols, such as gestures, sounds, words, and even morphemes.

Performance philology works to look at the symbols and makes sense of how they work and what they mean for the audience and the performers. It aims to make a stage performance in a certain local context understandable to wide audiences (readers) by providing explanatory commentaries on the symbols in performance process. In this purpose, I made a philological edition of a mak yong performance. Besides commentaries, the edition also provides the illustration of musical accompaniment and articulation of speech (cf. Arps 2016: 108-9). As is shown in the quote below, for instance, the symbols / $\bullet \bullet /$ represent the sound of a gong; while / «» / indicates an interruption in speech (1-2 seconds); and / — / indicates sustained speech. The edition is presented in three columns: the left one is my commentaries to the stage performance; the middle column represents the stage; and the right column is the audience's responses (italicized) and my view, as a member of the audience, to what is happening on stage (unitalicized in square brackets). Below is an example of how a philological approach is used to analyze the performance of the Raja Bungsu Sakti play at Festival Tamadun Melayu in Lingga in November 2017.

Baéklah: a formula that starts a narrator's speech and is used as an opener of the scene to attract audience's attention. Berape lame setengah umo $(r)$ exaggerates the length of Cik Wang's travel: half a lifetime.
CIK WANG: Baéklah, «»

berape lame setengah umo(r) saye

bejalan, saye sudah pun sampai di

laman pondok Awang. «»

Baéklah di sini tempat saye nak panggil

Awang, nak sayu Awang, nak ajak

Awang kire bicare. «»

Oh iya-lah mu Awang, Awang o-i!

Oh iya-lah mu Awang, Awang o-i!

$\bullet \bullet \bullet \bullet$

AWANG PENGASUH: hei, siape tu?
[Awang gestures and gazes at the audience in a comical way] Audience laughs and some of them shout: ' $O$ wang!' while others shout: 'parah Awang!'

Part of the edition above shows a scene in which the prince, Raja Bungsu Sakti, arrives infront of Awang Pengasuh's house after a trip from his royal court. A solo dance of the prince symbolizes the trip, which took about five minutes before being concluded with his arrival. During the solo dance, the members of the audience are chatting with each other, using their smartphones, and taking photos of the performers. In this performance context, the word "baéklah" is the first utterance made by the character of the prince (i.e. Pak Yong or Cik Wang) that can attract the audience's attention. Meanwhile, it also functions as a formula, by which the performer turns into a narrator telling the audience about the next stage action. Not only can utterances and acting be explained in this edition, but also comical gestures that have stimulated attention and responses from the audience. The description of stage, audience, timing, and the transition between and introduction to episodes is also part of the philological edition. Hence, with performance philology, we can make sense of the whole process of performance, from the meanings of local terms; certain motives or chunks of a story; dance movements and gestures; the significance of the audience's responses to the actors; and the meanings of other symbols, in the performance and sociocultural contexts.

\section{Concluding remarks}

The current sociocultural and political context of the Riau Islands shows that the revival of mak yong is interrelated with the formation of Malay identity of the region, the promotion of the tourist 
industry, and the making of official heritage of Indonesia. Mak yong has been presented and represented to the public through stage performances, museum exhibitions, heritage lists, newspapers articles, and television broadcastings. Hence, the current interests of the local and central governments, tourists and visitors, heritage-makers, and other institutions or agencies, have continuously (re)shaped mak yong as a revived tradition. Mak yong has been presented currently as a form of practices or "text", an intangible heritage, and a stage performance. In this sense, I apply multidisciplinary approaches to look at the above aspects of mak yong's presentation and representation from the perspectives of anthropology, heritage studies, and performance philology. These approaches with their analytical tools can help disentangle the social and cultural processes that (re)constitute mak yong as text and heritage. They are also instrumental to understand how symbols work in performance and what they imply in the performance and sociocultural contexts. I would argue that these multidisciplinary research approaches are relevant to study the revival and the current production of mak yong in Indonesia, and may apply to mak yong traditions in Malaysia and Thailand. It can also contribute to a scholarly understanding of the traditional art forms and performing arts in Southeast Asia at large.

\section{Acknowledgement}

This article is based on my $\mathrm{PhD}$ research project at Hamburg University. The project was funded by the German Academic Exchange Services (DAAD) under the scholarship program of Research Grants-Doctoral Programmes in Germany 2016/17.

\section{References}

Al Azhar (1989) Mak Yong Mantang Arang Kepulauan Riau: Cerita dan Pengungkapannya [Mak Yong in Mantang Arang, Riau Islands: Stories and Their Expression]. Paper presented at Seminar Hasil Penelitian Dalam Rangka Program Pernaskahan I Kerja Sama IndonesiaBelanda, 27-29 June, Jakarta.

Arps, B (2016) Tall Tree, Nest of the Wind: The Javanese Shadow-Play Dewa Ruci Performed by Ki Anom Soeroto: A Study in Performance Philology. Singapore: NUS Press.

Barber, K (2007) The Anthropology of Texts, Persons and Publics: Oral and Written Culture in Africa and Beyond. Cambridge: Cambridge University Press.

Haks, L (2005) Indonesia: 500 Early Postcards. Singapore: Editions Didier Millet.

Hardwick, PA (2013) Embodying the Divine and the Body Politics: Mak Yong Performance in Rural Kelantan, Malaysia. In: TP Daniels (ed.) Performance, Popular Culture and Piety in Muslim Southeast Asia. New York: Palgrave Macmillan, 77-104.

Hardwick, PA (2020) Mak yong, a UNESCO 'masterpiece': Negotiating the Intangibles of Cultural Heritage and Politicized Islam. Asian Ethnology, 79(1): 67-90.

Jones, T (2013) Culture, Power, and Authoritarianism in the Indonesian State: Cultural Policy Across the Twentieth Century to the Reform Era. Leiden and Boston: Brill.

Lumowah, B (1996) Mak yong: Teater Rakyat Riau [Mak Yong: Riau’s Folk Theatre]. Jakarta:

Departemen Pendidikan dan Kebudayaan Republik Indonesia.

Menick, R (1988) Syair Perkawinan Tik Sing [Malay Poem of Chinese Captain Tik Sing's Wedding]. MA thesis, Leiden University, Leiden.

Pudentia, MPSS (2010) The revitalization of Mak Yong in the Malay World. Wacana, 12(1): 1-19. 
Pudentia, MPSS (2000) Makyong: Hakikat dan Proses Penciptaan Kelisanan [Mak Yong: The Nature and the Creative Process of an Oral Tradition]. PhD thesis, Universitas Indonesia, Depok.

Van Der Putten, J (1997) Versified Awai Verified: Syair Awai by Raja Ali Haji. Indonesia and the Malay World, 72: 99-133.

Sastrosuwondho, S (1985) Teater Mak Yong dan Perkembangannya [Mak Yong Theatre and its Development]. Paper presented at Pertemuan Ilmiah Budaya Melayu, 17-21 July, Tanjung Pinang.

Sheppard, M (1972) Taman Indera: Malay Decorative Arts and Pastimes. Kuala Lumpur: Oxford University Press.

Syair Raja Nur Peri. Leiden University Library, [Klinkert 140]

Syamsuddin, BM (1982) Seni Peran Mak yong: Khazanah Budaya Warisan Bangsa [The Art of Acting of Mak Yong: Cultural Treasure and National Heritage]. Jakarta: Departemen Pendidikan dan Kebudayaan Republik Indonesia.

Tan, SB and A. S. Hardy Shafii (2021) A Tribute to the Remaining Makyong Performers of Yala, South Thailand. SPAFA Journal, 5: 1-11.

Waterton, E and Watson, S (eds.) (2015) The Palgrave Handbook of Contemporary Heritage Research. London, New York: Palgrave Macmillan.

Yousof, G-S (1982) Mak Yong, the Ancient Malay Dance Drama. Asian Studies, 20: 108-121.

Yousof, G-S (2018) Mak Yong Through the Ages: Kelantan's Traditional Dance Theatre. Kuala Lumpur: University of Malaya Press. 